\title{
Pengaruh Peran Bidan, Peran Keluarga, Persepsi Ibu, Konsep Diri Stres Pada Ibu Hamil Primigravida
}

\author{
Aprilya Nency \\ Program Studi Magister Kesehatan Masyarakat Sekolah Tinggi Ilmu Kesehatan Indonesia Maju \\ Jln. Harapan Nomor 50, Lenteng Agung - Jakarta Selatan 12610 \\ Telp: (021) 78894045 Email: aprilyanency@ gmail.com
}

\begin{abstract}
Abstrak
Stres seakan menjadi sesuatu yang sulit sekali dipisahkan dari masa-masa kehamilan seorang wanita. Terkadang sang calon ibu tak menyadari jika sedang mengalami stress, Tujuan Penelitian untuk mengetahui pengaruh langsung dan tidak langsung serta besarannya peran bidan, peran keluarga, persepsi ibu hamil, dan konsep diri terhadap stres pada ibu hamil Primigravida di Balai Pengobatan Mandiri Bidan W Citayam Jawa Barat. Metode penelitian ini adalah pendekatan kuantitatif dengan desain cross-sectional, Jumlah sampel 65 ibu hamil, Metode analisis dengan Structural Equation Model (SEM) mengunakan SmartPLS 2.0. Hasil temuan penelitian yaitu variabel-variabel Stres pada ibu hamil primigravida dipengaruhi oleh peran bidan $(0,92 \%)$, peran petugas kesehatan $(13,38 \%)$, persepsi $(2,14 \%)$, dan konsep diri $(19,66 \%)$,Total besaran pengaruh langsung terhadap stres pada ibu hamil primigravida sebesar $36,11 \%$ dan pengaruh tidak langsung sebesar 1,73\%. Peran keluarga dan konsep diri merupakan faktor yang dominan mempengaruhi stres pada ibu hamil primigravida. Model hasil analisis dapat menjelaskan $(70,77 \%)$ keragaman data dan mampu mengkaji fenomena yang dipakai dalam penelitian, sedangkan $(29,23 \%)$ dijelaskan komponen lain yang tidak ada dalam penelitian ini. Saran penelitian adalah agar bidan lebih meningkatkan peran keluarga terhadap ibu hamil primigravida dan konsep diri terhadap ibu hamil tersebut, dengan memberdayakan peran bidan dalam konseling pada ibu kehamilan
\end{abstract}

Kata Kunci $\quad$ : Peran bidan, Peran Keluarga, Persepsi, Konsep diri, Stres Ibu Primigravida

\begin{abstract}
Stress seemed to be something that is very difficult to be separated from periods of a woman's pregnancy. Sometimes the prospective mother is not aware if it is under stress. Stress condition generally characterized by symptoms of headache, anxiety, tension and abysmally. Metode this research is a quantitative approach to the cross-sectional design. Total sample of 65 patients with hypertension. The method of analysis by Structural Equation Model (SEM) using SmartPLS 2.0. The test results are hypothesis generating research findings variables maternal stress primigravidae influenced by the role of midwife $(0.92 \%)$, the role of health workers (13:38\%), perception $(2: 14 \%)$, and self-concept $(19.66 \%)$. Total direct impact on the amount of stress in pregnant women primigravida at $36.11 \%$ and the indirect effect of $1.73 \%$. family roles and the concept of self is the dominant factor affecting stress in pregnant women primigravida. Model analysis results can be explained $(70.77 \%)$ diversity data and capable of studying the phenomenon used in the study, while (29.23\%) described another component that does not exist in this study. Suggestion research is to increase the role of the family against primigravida pregnant women and the concept itself against pregnant women, by empowering the role of midwives in counseling on maternal pregnancy
\end{abstract}

Keywords: Role of midwives, Role of Family, perception, self concept, Stress Mother primigravida 


\section{Pendahuluan}

Setiap tahun sekitar 20.000 perempuan di indonesia meninggal akibat komplikasi dalam peesalinan. Melahirkan seharusnya menjadi peristiwa yang membahagiakan tetapi seringkali berubah menjadi sebuah tragedi. Sebenarnya, hampir semua kematian tersebut dapat dicegah. Oleh karena itu tujuan kelima MDG'S difokuskan pada kesehatan ibu, untuk mengurangi kematian ibu. ${ }^{1}$

Masalah kematian dan kesakitan ibu di Indonesia masih merupakan masalah besar. Angka Kematian Ibu (AKI) menurut Survei Demografi dan Kesehatan Indonesia (SDKI) tahun 2007 menyebutkan bahwa AKI nasional untuk periode 5 tahun sebelum survei (20032007) sebesar 228 per 100.000 kelahiran hidup. Angka ini lebih rendah dibandingkan AKI hasil SDKI tahun 2002-2003 yang mencapai 307 per 100.000 kelahiran hidup. Angka ini merupakan angka tertinggi di Asia Tenggara. Meskipun terjadi penurunan dan terlihat adanya kecenderungan menurun, namun apabila diamati penurunan yang terjadi belum menunjukkan angka yang signifikan dari yang di harapkan. ${ }^{2}$

Tahun 2013, Angka Kematian Ibu di Jawa Barat sebesar 837. Angka kematian bayi di Jawa Barat melebihi angka rata-rata kematian bayi nasional yaitu 36 bayi per 1000 bayi yang lahir. Sedangkan kematian bayi yang baru lahir masih di atas rata-rata dengan lebih kematian dari 1000 bayi yang lahir. Sementara itu, kejadian distosia bahu di Jawa Barat adalah $(0,2 \%)$ atau 2 per 1000 kelahiran hidup pervaginam. ${ }^{3}$

Tingginya AKI dan bayi di Indonesia merupakan indikator kesehatan yang masih menjadi prioritas utama khususnya dalam dunia kesehatan dengan tujuan mendongrak kesejahteraan perempuan Indonesia umumnya. Berdasarkan data yang diperoleh oleh SDKI tahun 2007 terdapat jumlah ibu yang meninggal sebanyak 228 dan pada tahun 2015 melonjak tajam sebanyak 359 ibu hamil yang meningal. Bila diperhatikan angka kematian ibu pada tahun 2015 yakni sebanyak 359, hal ini tidak sesuai dengan target pencapaian yang dilakukan oleh Millennium Development Goals MDG's dengan target sebanyak 102 kematian ibu hamil di Indonesia. ${ }^{4}$
Stres merupakan realitas kehidupan sehari-hari yang selalu ada dalam tiap tumbuh kembang manusia sejak bayi, anak-anak, dewasa, dan usia lanjut. Berdasarkan usianya masing-masing individu mengalami tingkat stres yang berbeda-beda. Berat ringannya stres yang dihadapi tidaklah selalu sama, hal ini dapat disebabkan oleh berbagai faktor antara lain: faktor lingkungan misal nya suara bising; fisik misal nya perubahan suhu terlalu tinggi atau terlalu rendah dan psikologis misalnya penyesuaian diri dalam hubungan interpersonal, sosial budaya atau keagamaan.

Stress merupakan suatu kondisi yang disebabkan adanya ketidaksesuaian antara situasi yang diinginkan dengan keadaan biologis, psikologis atau sistem sosial individu tersebut. Agolla dan Ongori juga mendifinisikan stres sebagai persepsi dari kesenjangan antara tuntutan lingkungan dan kemampuan individu untuk memenuhinya. ${ }^{5}$

Menurut Dr. Suparyanto stres yang berkepanjangan pada ibu hamil memberikan kontribusi hampir 35\% terhadap terjadinya ketuban pecah dini, hal ini dikarenakan pengaruh stres yang berkepanjngan yang dapat meningkatkan kadar hidramnion pada ibu hamil. Hidramnion merupakan kehamilan dengan jumlah air ketuban lebih dari 2 liter. Produksi air ketuban berlebih dapat merangsang persalinan sebelum kehamilan 28 minggu, sehingga dapat menyebabkan persalinan preterm dan dapat meningkatkan kejadian BBLR (Berat Badan Lahir Rendah) pada bayi. Sedangkan kontribusi stres yang berkepanjangan pada ibu hamil terhadap terjadinya persalinan preterm mencapai hampir $40 \%$, hal ini dikarenakan sistem saraf simpatetik (nor) adrenalin yang dialami ibu hamil dapat meningkatkan corticotrophinreleasing hormone $(\mathrm{CRH})$ diawal kehamilan sehingga mengakibatkan terjadinya penurunan jumlah jaringan kolagen dan terganggunya struktur kolagen, serta peningkatan aktivitas kolagenolitik. Degradasi kolagen tersebut terutama disebabkan oleh matriks metaloproteinase (MMP). MMP merupakan suatu grup enzim yang dapat memecah komponen-komponen matriks ektraseluler. Pada selaput ketuban juga diproduksi penghambat metaloproteinase/ tissue inhibitor metalloproteinase (TIMP). 
Ketidakseimbangan kedua enzim tersebut dapat menyebabkan degradasi patologis pada selaput ketuban sehingga ketuban menjadi pecah. dan sisanya $25 \%$ disebabkan oleh faktor-faktor yang lainnya. ${ }^{6}$

Pada tahun 2003 bagian Seksi Pelayanan Khusus Dinas Kesehatan Provinsi Jawa Barat bekerja sama dengan RS Jiwa Bandung, RS Jiwa Cimahi, dan Bagian Psikiatri FKUP/ RSHS melakukan survey kesehatan jiwa pada ibu hamil dan menyusui di 112 Puskesmas 24 kabupaten Provinsi Jawa Barat. Hasil penelitian ini menunjukkan, 798 orang atau(27\%) dari 2.928 responden ibu hamil dan menyusui, menunjukkan tanda gangguan psikiatri berupa stress pada saat kehamilan. $^{7}$

Survei awal yang di lakukan di Balai Pengobatan Mandiri Bidan W Citayam Jawa Barat pada tahun 2014 didapatkan 347 ibu hamil yang melakukan pemeriksaan kehamilan, pada tahun 2015 didapatkan 403 ibu yang melakukan pemeriksaan kehamilan dan tahun 2016 terdapat 510 pemeriksaan ibu hamil, dan setiap tahunnya ibu yang mengalami kecemasan, depresi hingga stress terdapat $30 \%$ pertahunnya.

Tujuan penelitian ini adalah untuk mengetahui pengauh langsung dan tidak langsung peran bidan, peran keluarga, persepsi Ibu, dan konsep diri terhadap stres pada Ibu hamil primigravida di Balai Pengobatan Mandiri Bidan

\section{Metode}

Penelitian ini adalah penelitian penelitian kuantitatif dengan desain cross sectional yang gunanya untuk menganalisis hubungan kausal antara variabel-variabel melalui pengujian hipotesis yaitu untuk menganalisis pengaruh langsung dan tidak langsung serta besarannya antara Peran Bidan, Peran Keluarga, Persepsi Ibu, dan Konsep Diri Terhadap Stres pada Ibu Hamil Primigravida Populasi dalam penelitian ini adalah seluruh ibu hamil primigravida yang kunjungan ke BPM Bd. W Citayam Jawa Barat. yang berjumlah 65 orang. Waktu penelitian februari 2017, Adapun teknik pengambilan sampel dengan menggunakan Accidental Sampling. ${ }^{8}$ Pengambilan sampel berdasarkan kriteria inklusi yaitu ibu hamil primigravida yang berkunjung ke BPM Bd. W dan bersedia menjadi responden. Kriteria eksklusi dalam penelitian ini adalah ibu hamil primigravida yang menolak dan mengundurkan diri ikut serta dalam penelitian ini.

Jumlah sampel tersebut diambil sesuai dengan kaidah jumlah sampel pada pedoman (Partial Least Squares) PLS. dengan rumusan, dimana besaran sampel (Sample size) yang diambil adalah 5 hingga 10 kelipatan dari jumlah indikator yang akan diteliti. ${ }^{9}$ Sehingga jumlah indikator yang digunakan dalam penelitian ini adalah 9 maka ukuran sampelnya berada pada rentang 45-90. Berdasarkan pertimbangan tersebut maka ukuran sampel dalam penelitian ini ditetapkan sebanyak 65 responden

Metode analisis data yang digunakan dalam penelitian ini adalah analisis univariat, analisis bivariate dan analisis Structural Equation Modelling (SEM). Diagram jalur berfungsi untuk menunjukkan pola hubungan antar variabel yang akan diteliti. Dalam SEM pola hubungan antar varaibel akan diisi dengan variabel yang diobservasi, variabel laten dan indikator. Data penelitian ini disajikan dalam bentuk (1) penyajian komposisi dan frekuensi dari sampel. Data yang disajikan pada awal hasil analisa adalah berupa gambaran atau deskripsi mengenai sampel, dimana penjelsan juga disetai ringkasan berupa tabel dari deskripsi yang utama.Hal ini dilakukan untuk membantu pembaca lebih mengenal karakteristik dari responden dimana data penelitian tersebut diperoleh. (2) Penyajian analisa SEM. Data penyajian analisa SEM dari pengolahan data output yang menggunakan bantuan SPSS 18.0 dan SmatPLS 2.0, disajikan dalam diagram, tabel dan gambar. ${ }^{10}$

\section{Hasil}

Hasil penelitian tentang karakteristik responden sebagian besar ibu hamil berusia 20 - 35 tahun sebanyak 36 responden $(55,4 \%)$. Berdasarkan pendidikan ibu hamil memperlihatkan bahwa sebagian besar responden adalah berpendidikan tinggi yaitu sebanyak 43 responden $(66,2 \%)$. Sedangkan berdasarkan pekerjaan memperlihatkan bahwa sebagian besar ibu hamil tidak bekerja sebanyak 33 responden $(50,8 \%)$.

Gambar 1 terlihat bahwa nilai faktor loading telah memenuhi persyaratan yaitu nilai loading factors diatas 0,5. Suatu indikator reflektif dinyatakan valid jika mempunyai loading factor diatas 0,5 terhadap konstruk 
yang dituju berdasarkan pada substantive content-nya dengan melihat signifikansi dari weight $(\mathrm{t}=1,96)$.

Hasil analisis pengolahan data terlihat bahwa konstruk yang digunakan untuk membentuk sebuah model penelitian, pada proses analisis faktor konfirmatori telah memenuhi kriteria nilai di atas batas signifikansi yaitu 0,05. Dari hasil pengolahan data di atas, juga terlihat bahwa setiap indikator atau dimensi pembentuk

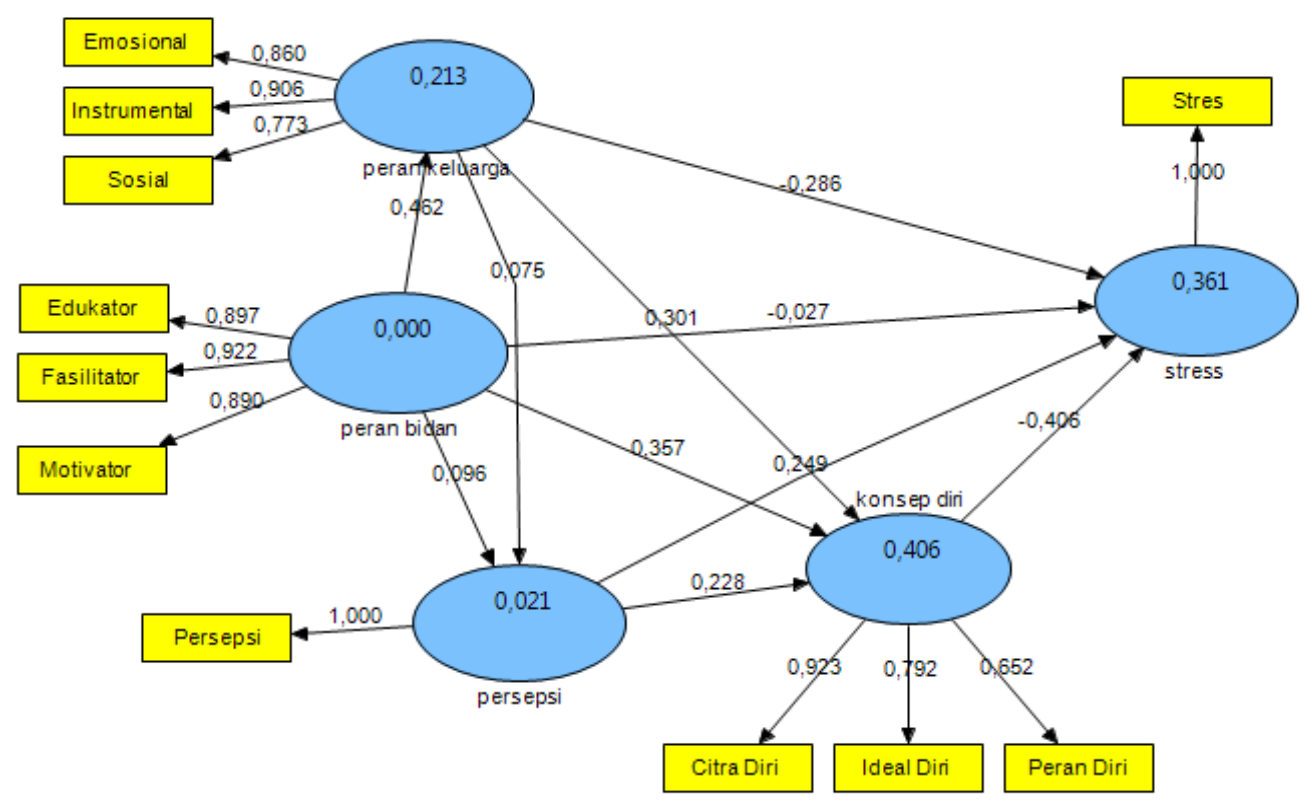

Gambar 1. Output PLS (Loading Factors)

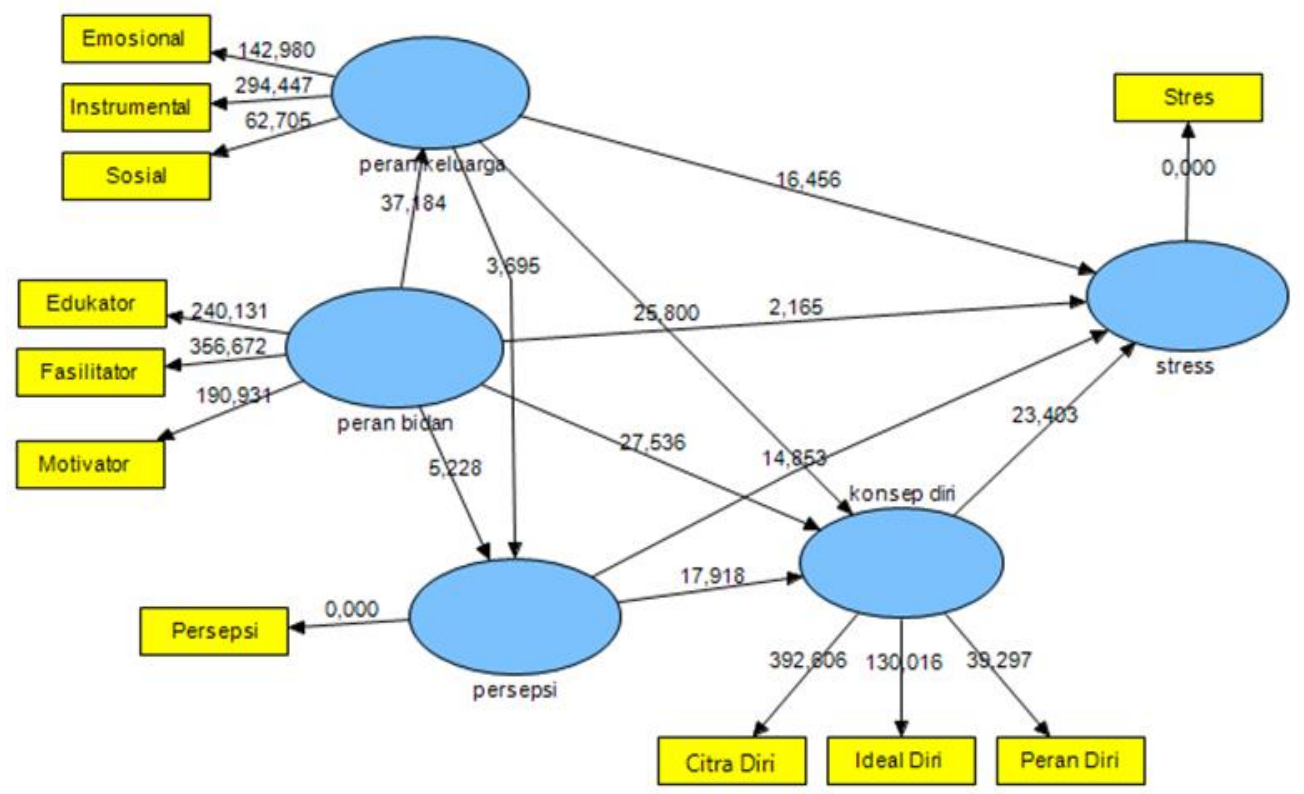

Gambar 2.Model (T-Statistic) Bootstrapping 
variabel laten menunjukkan hasil yang baik, yaitu dengan nilai loading factor yang tinggi di mana masing-masing indikator lebih besar dari0,5. Dengan hasil ini, maka dapat dikatakan bahwa indikator pembentuk variabel laten konstruk Peran Bidan, Peran Keluarga, Persepsi Ibu, dan Konsep Diri Terhadap Stres pada Ibu Hamil Primigravida tersebut sudah menunjukkan hasil yang baik. Setelah dilakukan uji validitas dan telah dinyatakan valid variabel dan indikatornya untuk selanjutnya dilakukan uji reliabilitas. uji reliabilitas ini dilakukan dengan melihat nilai composite reliability dari blok indicator yang mengukur konstruk hasil composite reliability yang akan menunjukkan nilai yang memuaskan jika diatas 0,70, hasil uji menunjukkan bahwa semua variabel dinyatakan reliable karena nilai Cronbach's Alpha dan Composite reliability diatas 0,70 sehingga dapat dikatakan bahwa kontruk memiliki reliabilitas yang baik. Gambar 2 menyatakan nilai T-Statistik direfleksikan terhadap variabelnya sebagian besar > 1,96, sehingga menunjukan blok indikator berpengaruh positif dan signifikan untuk merefleksikan variabelnya.

Tabel 1. Hasil Pengukuran $R$-Square

\begin{tabular}{lc}
\hline \multicolumn{1}{c}{ Variabel } & R Square \\
\hline Konsep Diri & 0,405936 \\
Peran Bidan & \\
Peran Keluarga & 0,213122 \\
Persepsi & 0,021399 \\
Stres & 0,361069 \\
\hline
\end{tabular}

Sumber : SmartPLS 2.0 report, 2017

Dari tabel 1 diatas dapat dilihat bahwa Nilai $r$ square pada Peran Bidan berkontribusi terhadap variabilitas Peran Keluarga sebesar $52,25 \%$ dan $47,75 \%$ dijelaskan oleh variabel lain yang tidak diteliti. Variabilitas Peran Keluarga dan Peran Bidan berkontribusi terhadap variabilitas Persepsi sebesar 2,14\% dan $97,86 \%$ dijelaskan oleh variabel lain yang tidak diteliti. Variabilitas Peran Keluarga, Peran Bidan dan Persepsi berkontribusi terhadap variabilitas Konsep Diri sebesar 40,6\% dan 59,4\% dijelaskan oleh variabel lain yang tidak diteliti. Variabilitas Peran Keluarga, Peran Bidan, Persepsi dan Konsep Diri berkontribusi terhadap variabilitas Stres sebesar $36,11 \%$ dan $63,89 \%$ dijelaskan oleh variabel lain yang tidak diteliti.

Berdasarkan gambar 2 di memperlihatkan bahwa Peran Bidan berpengaruh positif terhadap Peran Keluarga, hasil uji menunjukkan ada pengaruh positif 0,461651 , sedangkan nilai T-Statistic sebesar 37,184383 dan signifikan pada $\alpha=5 \%$. Nilai $T$ Statistic tersebut berada di atas nilai kritis $(1,96)$. Peran Bidan berpengaruh positif terhadap Persepsi, hasil uji menunjukkan ada pengaruh positif 0,095891 , sedangkan nilai $T$ Statistic sebesar 5,228174 dan signifikan pada $\alpha=5 \%$. Nilai $T$-Statistic tersebut berada di atas nilai kritis $(1,96)$. Peran Bidan berpengaruh positif terhadap Konsep Diri, hasil uji menunjukkan ada pengaruh positif 0,356650 , sedangkan nilai $T$-Statistic sebesar 27,535566 dan signifikan pada $\alpha=5 \%$. Nilai T-Statistic tersebut berada di atas nilai kritis $(1,96)$. Peran Bidan berpengaruh negatif terhadap Stres, hasil uji menunjukkan ada pengaruh negatif0,027164 , sedangkan nilai $T$-Statistic sebesar 2,164741 dan signifikan pada $\alpha=5 \%$. Nilai $T$ Statistic tersebut berada di atas nilai kritis $(1,96)$. Peran Keluarga berpengaruh positif terhadap Persepsi, hasil uji menunjukkan ada pengaruh positif 0,074745 , sedangkan nilai $T$ Statistic sebesar 3,694905 dan signifikan pada $\alpha=5 \%$. Nilai $T$-Statistic tersebut berada di atas nilai kritis $(1,96)$. Peran Keluarga berpengaruh positif terhadap Konsep Diri, hasil uji menunjukkan ada pengaruh positif.Tabel 2 menyatakan menyatakan bahwa peran bidan berpengaruh secara langsung dan tidak langsung terhadap Stres. Hasil uji koefisien parameter antara Peran Bidan terhadap Stres menunjukkan terdapat pengaruh langsung sebesar 0,92\%, sedangkan untuk pengaruh tidak langsung antara Peran Bidan terhadap Stres melalui Peran Keluarga, Persepsi maupun Konsep Diri mendapat nilai sebesar $0,24 \%$. Peran Keluarga berpengaruh secara langsung dan tidak langsung terhadap Stres. Hasil uji koefisien parameter antara Peran Keluarga terhadap Stres menunjukkan terdapat pengaruh langsung sebesar $13,38 \%$, sedangkan untuk pengaruh tidak langsung antara Peran Keluarga terhadap Stres melalui Persepsi maupun Konsep Diri mendapat nilai sebesar $0,10 \%$. 0,249448, sedangkan nilai $T$-Statistic sebesar 14,852680 dan signifikan pada $\alpha=5 \%$. Nilai T-Statistic tersebut berada di atas nilai kritis $(1,96)$. Konsep Diri berpengaruh negatif 
terhadap Stres, hasil uji menunjukkan ada pengaruh negatif $-0,406250$, sedangkan nilai $T$ Statistic sebesar 23,403352 dan signifikan pada $\alpha=5 \%$. Nilai $T$-Statistic tersebut berada di atas nilai kritis $(1,96)$. Berdasarkan gambar 1 tersebut menyatakan bahwa peran bidan mempunyai nilai tertinggi terhadap peran keluarga dengan nilai original sampel (Rho) sebesar 37,184. Sedangkan nilai pengaruh yang paling rendah adalah nilai peran bidan terhadap stres dengan nilai sebesar 2,164. Nilai terbesar kedua adalah nilai dari peran bidan terhadap konsep diri dengan nilai sebesar 27,53 Persepsi berpengaruh secara langsung dan tidak langsung terhadap Stres. Hasil uji koefisien parameter antara Persepsi terhadap Stres menunjukkan terdapat pengaruh langsung sebesar 2,14\%, sedangkan untuk pengaruh tidak langsung antara Persepsi terhadap Stres melalui Konsep Diri mendapat nilai sebesar 1,39\%. Konsep Diri berpengaruh secara langsung terhadap Stres. Hasil uji koefisien parameter antara Konsep Diri terhadap Stres menunjukkan terdapat pengaruh langsung sebesar $19,66 \%$. Sehingga nilai dari masing-masing pengaruh langsung variabel laten independen tersebut apabila secara bersama-sama menunjukkan kesesuaian dengan nilai $R$ Square atau dengan kata lain hal ini menyatakan bahwa variabel Peran Bidan, Konsep Diri, dan Persepsi mampu menjelaskan variabel Stres. sebesar $(0,92 \%+$ $13,38 \%+2,14 \%+19,66 \%)=36,11 \%$. Secara matematis bentuk persamaan structural dari model penelitian ini adalah sebagai berikut :

$\eta 1=\xi_{1} \gamma 1+\zeta 1$

Peran Keluarga $\quad=0,462 \times$ Peran Bidan + 0,538 .

$$
\eta 2=\xi 1 \gamma 2+\eta 1 . \beta 1+\zeta 2
$$

Persepsi $=0,096 \times$ Peran Bidan $+0,075 \mathrm{x}$

Peran Keluarga $+0,827$

$\eta 3=\xi_{1} \gamma 3+\eta 1 . \beta 4+\eta 2 . \beta 3+{ }_{\zeta 3}$

Konsep Diri $=0,357 \mathrm{x}$ Peran Bidan $+0,249 \mathrm{x}$

Peran Keluarga $+0,228 \times$ Persepsi $+0,166$

$\eta 4=\xi_{1} \gamma 4+\eta 3 . \beta 5+\eta 2 . \beta 2+\eta 1 . \beta 6+\zeta 4$

Stres $=-0,027 \times$ Peran Bidan $+-0,286 \times$ Peran

Keluarga $+0,249$ x Persepsi $+-0,406 \mathrm{x}$

Konsep Diri + 1,272

Nilai $Q$-Square berfungsi untuk menilai besaran keragaman atau variasi data penelitian terhadap fenomena yang sedang dikaji dan hasilnya sebagai berikut:

$$
\begin{aligned}
77 \% Q^{2}= & 1-\left(1-\mathrm{R}_{1}^{2}\right)\left(1-\mathrm{R}_{2}^{2}\right)\left(1-\mathrm{R}_{3}^{2}\right)(1- \\
& \left.\mathrm{R}_{4}^{2}\right) \\
Q^{2}= & 1-((1-0,405936) \times(1- \\
& 0,213122) \times(1-0,021399) \times \\
& (1-0,361069)) \\
Q^{2}= & 0,7077 \Rightarrow 70,77 \%
\end{aligned}
$$

Galat Model $=100 \%-70,77 \%=69,77 \%$

Hasil tersebut menunjukkan model hasil analisis yang dapat menjelaskan $70,77 \%$ keragaman data dan mampu mengkaji fenomena yang dipakai dalam penelitian, sedangkan $69,77 \%$ menjelaskan komponen lain yang tidak terdapat dalam penelitian ini.

Tabel 2. Persentase Pengaruh Antar Variabel Peran Bidan, Peran Keluarga, Persepsi, Konsep Diri, dan Stres di Balai Pengobatan Mandiri

\begin{tabular}{cccccccc}
\hline Sumber & $\begin{array}{c}\boldsymbol{L} \boldsymbol{V} \\
\text { Correlation }\end{array}$ & $\begin{array}{c}\text { Direct } \\
\text { Path }\end{array}$ & $\begin{array}{c}\text { Inderect } \\
\text { Path }\end{array}$ & Total & $\begin{array}{c}\text { Direct } \\
\mathbf{\%}\end{array}$ & $\begin{array}{c}\text { Indirect } \\
\mathbf{\%}\end{array}$ & $\begin{array}{c}\text { Total } \\
\boldsymbol{\%}\end{array}$ \\
\hline Peran Bidan (PB) & 0,340 & 0,027 & $-0,313$ & $-0,340$ & 0,92 & 0,24 & 1,16 \\
Peran Keluarga (PK) & 0,469 & 0,286 & $-0,110$ & 0,396 & 13,38 & 0,10 & 13,49 \\
Persepsi (PIH) & 0,086 & 0,249 & $-0,093$ & 0,157 & 2,14 & 1,39 & 3,53 \\
Konsep Diri (KD) & 0,484 & 0,406 & & $-0,406$ & 19,66 & & 19,66 \\
\hline & Total & & & & $\mathbf{3 6 , 1 1}$ & $\mathbf{1 , 7 3}$ & $\mathbf{3 7 , 8 4}$ \\
\hline
\end{tabular}

Sumber: Diolah dari SmartPLS 2.0 report 2017 
Pembahasan

\section{Pengaruh Peran Bidan Terhadap Stres Pada Ibu Hamil Primigravida di Balai Pengobatan Mandiri Bidan W}

Hasil uji terhadap koefisien parameter antara peran bidan terhadap stres pada ibu hamil primigravida di balai pengobatan mandiri Bidan W Citayam Jawa Barat Tahun 2017. menunjukkan terdapat pengaruh langsung sebesar $0,92 \%$. Variabel peran bidan memiliki pengaruh yang negatif secara signifikan terhadap nilai $T$-Statistic sebesar 2,164 dan signifikan pada $\alpha=5 \%$. Nilai $T$ Statistic tersebut berada diatas nilai kritis $(1,96)$. Artinya hasil penelitian menunjukkan, terdapat pengaruh yang negatif dari peran bidan terhadap stres pada ibu hamil primigravida di balai pengobatan mandiri Bidan W Citayam Jawa Barat Tahun 2017. Sehingga apabila peran bidan ditingkatkan maka dapat menurunkan stres pada ibu hamil primigravida secara langsung, begitupun sebaliknya apabila peran bidan menurun atau tidak diperhatikan akan meningkatkan terjadinya stres pada ibu hamil primigravida secara langsung.

Dari ketiga indikator ukur yang dimiliki variabel peran bidan, semua indikator mampu menjelaskan variabel peran bidan, hal ini membuktikan teori oleh Hendrikus Triwibawanto, peran bidan memiliki peranan yang sangat penting dalam meningkatkan partisipasi individu dalam program kesehatan, peran bidan berupa informasi atau nasehat verbal dan non verbal, bantuan nyata, atau tindakan yang diberikan oleh keakraban sosial atau dapat dikatakan karena adanya kehadiran mereka mempunyai manfaat emosional atau efek perilaku bagi pihak penerimanya. Peran tenaga kesehatan bisa mengubah perilaku kesehatan individu supaya bisa berpartisipasi dalam program kesehatan yang akan memberikan kontribusi penting pada kesehatan $^{11}$

Hasil penelitian ini diperkuat oleh penelitian Parawita shinta yang berjudul pengaruh peran tenaga kesehatan, peran keluarga dan lingkungan sosial terhadap stres pada ibu hamil primigravida di wilayah kerja Puskesmas Tegalrejo. Hasil penelitian tersebut menunjukan bahwa peran bidan berpengaruh negatif terhadap stres pada ibu hamil. ${ }^{12}$
Pengaruh tidak langsung peran bidan terhadap stres pada ibu hamil primigravida di Balai Pengobatan Mandiri Bidan W Citayem Jawa barat melalui konsep diri, peran keluarga dan persepsi di BPM Bidan W Citayem Jawa Barat sebesar 0,24\%. Pengaruh tidak langsung stres terhadap stres pada ibu hamil primigravida di Balai Pengobatan Mandiri Bidan W Citayem Jawa barat melalui peran keluarga, persepsi dan konsep diri dilalui oleh 7 (tujuh jalur). Berdasarkan hasil uji tersebut dapat dijelaskan bahwa pengaruh tidak langsung peran bidan terhadap stress dipengaruhi oleh variabel peran keluarga sebesar 0,102\%, variabel persepsi sebesar $0,001 \%$ dan variabel konsep diri sebesar $0,131 \%$. Hasil persentase pengaruh tidak langsung peran bidan terhadap stres pada ibu hamil primigravida di Balai Pengobatan Mandiri Bidan W Citayem Jawa barat di dominasi oleh faktor konsep diri.

Penelitian ini sejalan dengan teori Yuni Permatasari yang menyatakan bahwa tenaga kesehatan seperti bidan memberikan informasi kesehatan kepada anggota keluarga tentang kesehatan ibu pada masa kehamilan, sehingga anggota keluarga berperan membantu menolong kesehatan ibu dan anak. Hal ini sejalan dengan jurnal yang menyatakan bahwa peran keluarga diperoleh nilai koefisien korelasi (r) sebesar $-0,436 ; p=0,13(p<0,05)$ hasil tersebut menunjukan ada hubungan yang signifikan. ${ }^{13}$

\section{Pengaruh Peran Keluarga Terhadap Stres Pada Ibu Hamil Primigravida di Balai Pengobatan Mandiri}

Hasil uji terhadap koefisien parameter antara peran keluarga terhadap Stres pada ibu hamil primigravida di Balai Pengobatan Mandiri Bidan W Citayem Jawa barat menunjukkan terdapat pengaruh langsung sebesar 13,38\%. Variabel peran keluarga memiliki pengaruh yang negatif secara signifikan terhadap nilai $\mathrm{T}$-Statistic sebesar 16,45 dan signifikan pada $\alpha=5 \%$. Nilai TStatistic tersebut berada diatas nilai kritis $(1,96)$.

Hasil penelitian menunjukkan, terdapat pengaruh yang negatif dari peran keluarga terhadap stres pada ibu hamil primigravida di Balai Pengobatan Mandiri Bidan W Citayem Jawa barat. Sehingga apabila peran keluarga ditingkatkan dapat memberikan kenyamanan 
fisik dan psikologis secara langsung, begitupun sebaliknya apabila peran keluarga tidak diberikan dapat mengakibatkan stres terhadap ibu hamil primigravida secara langsung ${ }^{14}$

Menurut Sudiharto Peran keluarga merupakan peran yang diberikan keluarga dalam pengambilan keputusan untuk kesehatan seseorang. keluarga adalah orang pertama dan utama dalam memberi dorongan sebelum pihak lain. Peran keluarga akan memberikan rasa nyaman dan memberikan dorongan, motivasi terhadap anggota keluarga, baik secara moral maupun material. ${ }^{15}$

Hasil uji terhadap koefisien parameter pengaruh tidak langsung antara peran keluarga terhadap stres pada ibu hamil primigravida di Balai Pengobatan Mandiri Bidan W Citayam Jawa barat sebesar $0.10 \%$. pengaruh tidak langsung antara peran keluarga terhadap stres pada ibu hamil primigravida di Balai Pengobatan Mandiri Bidan W Citayem Jawa barat melalui persepsi dan konsep diri dilalui oleh 3 (tiga jalur). Berdasarkan hasil uji tersebut dapat dijelaskan bahwa pengaruh tidak langsung peran keluarga terhadap stress dipengaruhi oleh variabel persepsi sebesar $0.001 \%$ dan variabel konsep diri sebesar $0.104 \%$. Hasil persentase pengaruh tidak langsung peran keluarga terhadap stres pada ibu hamil primigravida di Balai Pengobatan Mandiri Bidan W Citayam Jawa barat lebih didominasi oleh faktor konsep diri.

Teori oleh Shochib menyatakan Keluarga merupakan lingkungan sosial yang selalu ditemui suatu individu dalam kehidupannya sehari-hari, Peran serta keluarga memberikan pengaruh yang besar terhadap perkembangan konsep diri ibu, keluarga akan memberikan informasi yang besar terhadap perkembangan konsep diri individu. keluarga juga dapat mengajarkan bagaimana cara menilai dirinya sendiri. Jika tidak ada peran keluarga akan, mengalami kesulitan dalam menjalankan kegiatan dan memperoleh informasi tentang kesehatan dirinya sehingga hal ini kan membentuk konsep diri negatif ibu hamil. ${ }^{16}$

\section{Pengaruh Persepsi Ibu Hamil Terhadap Stres pada Ibu Hamil Primigravida di Balai Pengobatan Mandiri}

Hasil uji terhadap koefisien parameter antara persepsi ibu hamil terhadap Stres pada ibu hamil primigravida di Balai Pengobatan Mandiri Bidan W Citayem Jawa barat menunjukkan terdapat pengaruh langsung sebesar 2,14\%. Variabel persepsi ibu hamil memiliki pengaruh yang positif secara signifikan terhadap nilai $\mathrm{T}$-Statistic sebesar 14,85 dan signifikan pada $\alpha=5 \%$. Nilai $\mathrm{T}$ Statistic tersebut berada diatas nilai kritis $(1,96)$. Artinya hasil penelitian menunjukkan terdapat pengaruh yang positif dari persepsi ibu hamil terhadap Stres pada ibu hamil primigravida di Balai Pengobatan Mandiri Bidan W Citayam Jawa barat

Teori yang menjelaskan tentang hasil penelitian adalah teori dari Friedman yang menyatakan bahwa persepsi adalah kegiatan menyortir, menginterpretasikan, menganalisis dan mengintegrasikan rangsang (stimulus) yang dibawa oleh organ indera dan otak. Gulo 1982 juga mendefinisikan persepsi sebagai proses seseorang menjadi sadar akan segala sesuatu dalam lingkungannya melalui inderaindera. ${ }^{17}$

Hal ini sejalan dengan hasil penelitian Pasek et al yang menyatakan bahwa terdapat hubungan antara persepsi dengan stress selama kehamilan, dimana ibu hamil yang memiliki persepsi positif mengenai kehamilan memiliki kemungkinan untuk tidak sters dalam kehamilan dibandingkan ibu hamil yang memiliki persepsi negatif. ${ }^{18}$

Berdasarkan hasil penelitian Nurani di Boyolali dengan judul analisis faktor-faktor yang berpengaruh terhadap kejadian sters pada ibu hamil, didapatkan nilai $\mathrm{p}$ value $=0,009$ dengan $\mathrm{OR}=5,228$ artinya ada hubungan antara persepsi ibu terhadap kejadian stress pada saat kehamilan, dimana persepsi berpengaruh 5,228 kali terhadap kejadian stres pada ibu hamil. ${ }^{19}$

Persepsi terhadap terhadap Stres pada ibu hamil primigravida di Balai Pengobatan Mandiri Bidan W Citayem Jawa barat menunjukkan terdapat pengaruh tidak langsung sebesar 1,39\%. Pengaruh tidak langsung persepsi terhadap ibu hamil terhadap stres pada ibu hamil primigravida di Balai Pengobatan Mandiri Bidan W Citayem Jawa barat melalui konsep diri dilalui oleh 1 (satu jalur). Berdasarkan hasil uji tersebut dapat dijelaskan bahwa pengaruh tidak langsug persepsi terhadap Stres pada ibu hamil 
primigravida hanya dipengaruhi oleh variabel konsep diri sebesar 1,39\%.

Hasil penelitian ini sejalan dengan teori yang telah dikembangkan dimana secara umum stres dipengaruhi oleh faktor internal dan faktor eksternal. Menurut Steer salah satu penyebab stres adalah konsep diri, dalam hal ini konsep diri negatif yang ditekankan dapat memberikan pengaruh internal terhadap tingginya. $^{20}$

Berdasarkan hasil penelitian Tanjung sari, bahwa konsep diri ibu hamil berpengaruh positif dan signifikan terhadap sters ibu hamil di BPS Bd. Handyani Magetan Jawa Timur, Hasil uji kedua variabel menunjukkan ada pengaruh positif sebesar 13,6\%, sedangkan nilai T-Statistic 3,993. Nilai T-Statistic tersebut berada diatas nilai kritis $(1,96) .{ }^{21}$

\section{Pengaruh Variabel Konsep Diri Terhadap Stres pada Ibu Hamil Primigravida di Balai Pengobatan Mandiri}

Hasil uji terhadap koefisien parameter antara Konsep Diri terhadap terhadap Stres pada ibu hamil primigravida di Balai Pengobatan Mandiri Bidan W Citayem Jawa barat menunjukkan terdapat pengaruh langsung sebesar 19,66\%. Sedangkan untuk pengaruh tidak

langsung Konsep Diri terhadap terhadap Stres pada ibu hamil primigravida di Balai Pengobatan Mandiri Bidan W Citayem Jawa barat tidak ada nilai yang mempengaruhinya. Hasil uji terhadap koefisien parameter antara Konsep Diri terhadap terhadap Stres pada ibu hamil primigravida di Balai Pengobatan Mandiri Bidan W Citayem Jawa bara menunjukan ada pengaruh positif dengan nilai T-Statistik signifikan sebesar 23,40 pada $\alpha=5 \%$. Nilai T-Statistic tersebut berada jauh diatas nilai kritis $(1,96)$.

Konsep diri diartikan sebagai keseluruhan dari pola pikir individu dalam menentukan perasaannya. Dengan kata lain, konsep diri merupakan komponen yang berasal dari sikap individu terhadap diri yang individu miliki. Konsep diri adalah cara seseorang untuk melihat dirinya secara utuh dengan semua ide, pikiran, kepercayaan, dan pendirian yang diketahui individu dalam berhubungan dengan orang lain. ${ }^{22}$

Penelitian Dewi telah membuktikan ada pengaruh konsep diri ibu hamil terhadap sters pada masa kehamilian. Faktor predisposisi meliputi peristiwa traumatik yang mendalam, konflik emosional, konsep diri yang terganggu, frustasi dan gangguan fisik. Faktor presipitasi lebih cenderung mengarah kepada hal-hal yang bersifat ancaman kepada diri sendiri, seperti ancaman integritas fisik dan ancaman harga diri. Penelitian ini, stres yang dialami subjek penelitian mengarah kepada salah satu faktor predisposisi yaitu konsep diri ${ }^{23}$

\section{Kesimpulan}

Penelitian ini menyimpulkan bahwa Stres pada ibu hamil primigravida di Balai Pengobatan Mandiri Bidan W Citayam Jawa barat dipengaruhi oleh peran bidan $(0,92 \%)$, peran keluarga $(13,38 \%)$, persepsi $(2,14 \%)$ dan konsep diri $(19,66 \%)$.

\section{Saran}

Perlunya memperhatikan faktor - faktor stres dalam kehamilan seperti variabel konsep diri untuk ditingkatkan karena terbukti memberikan kontribusi yang baik terhadap kejadian stress pada ibu hamil misalnya dengan cara meningkatkan peran keluarga, pada dasarnya peran suami mendominasi dalam memutuskan tindakan karena suami yang bertindak sebagai kepala keluarga dan mayoritas pengambil keputusan dalam kesehatan ibu dan bayi. Sehingga diharapkan untuk semua keluarga dapat berperan aktif dalam memberikan dukungan, informasi seputar kehamilan dan pada akhirnya ibu memiliki konsep diri agar terhidar dari stress pada masa kehamilan kususnya ibu primigravida.

\section{Daftar Pustaka}

1. Dinkes Profinsi Dki Jakarta, Profil Kesehatan fokus MDG'S. 2016.

2. Departemen Kesehatan RI bekerjasama dengan Direktur Bina Kesehatan. Keluarga.Survei Demografi dan Kesehatan Indonesia. 2007.

3. Dinkes Kabupaten Profil Dinas Kesehatan Garut: 2013.

4. SDKI.Survei Kesehatan ibu dan anak. KepMenkes 2015.

5. Sarafino, E.P. Healt Psychology : Biopsychosocial Interactions. Fifth Edition. USA : John Wiley \& Son.2000.

6. Suprapti. Pengaruh stres dan ketuban pecah dini terhadap persalinan preterem dalam penelitian tesis nya di STIKIM; 2014. 
7. Dinkes Kabupaten Profil Dinas Kesehatan Garut: 2003.

8. Nursalam. Konsep dan Penerapan Metodologi Penelitian Ilmu Keperawatan (Edisi 2). Jakarta: Salemba Medika;2011.

9. Latan H. Structural equation modeling konsep dan aplikasi menggunakan program SmartPLS 2.0. Bandung: Alfabeta; 2012

10. Ghozali I. Structural Quation Modeling Metode Alternatif Partial Least Square (PLS), UNDIP, SEMARANG; 2011.

11. Triwibawanto Hendrikus. Peran Bidan. Bandung: EGC;2010.

12. Parawita shinta penelitian pengaruh peran tenaga kesehatan, peran keluarga dan lingkungan sosial terhadap stres pada ibu hamil primigravida di wilayah kerja Puskesmas Tegalrejo; 2015.

13. Permatasari yani jurnal pengaruh Peran Bidan terhadap ibu hamil terhadap stres:2011.
14. Sudiharto. Psikologi Perawatan. Jakarta: Grasindo;2008.

15. Shochib. Pola asuh keluarga . Jakarta : PT. Rineka Cipta;2010.

16. Friedman. Keperawatan Keluarga: Teori dan Praktek-ed-3. Jakarta: EGC;2008.

17. Pasek et al. Hubungan antara persepsi dengan stress selama kehamilan

18. Nurani. di Boyolali dengan judul analisis faktor-faktor yang berpengaruh terhadap kejadian sters pada ibu hamil.2010

19. Steer P, Flint C. ABC of labour care Preterm labour and prematur rupture of membrans. BMJ volume 318, April 1999. http://www.bmj.com._17/07/2013.22:363.

20. Tanjung sari. jurnal konsep diri ibu hamil.2014

21. Singgih. Psikologi Perawatan. Jakarta: Grasindo;2008.

22. Dewi. jurnal pengaruh konsep diri ibu hamil terhadap sters pada masa kehamilan.2013. 